SJîñn Jurnal

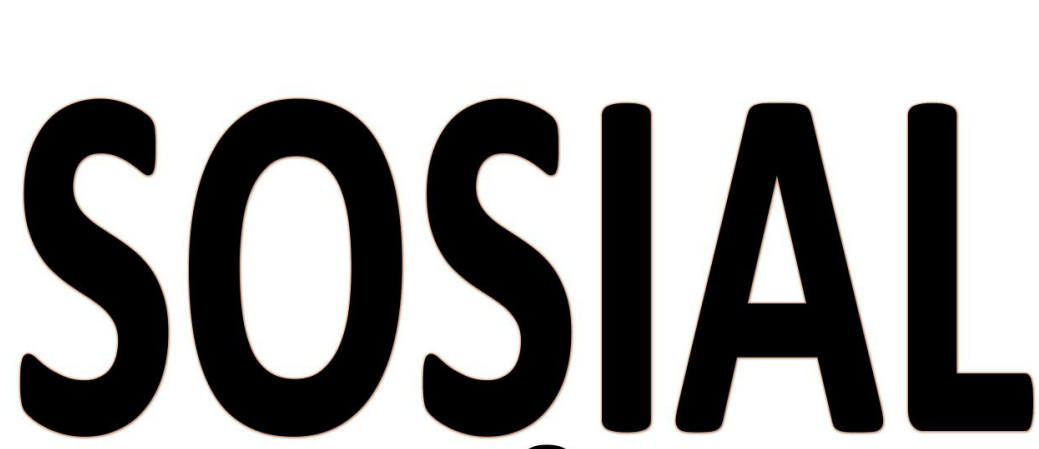

P-ISSN: 2356-1459 E-ISSN: 2654-9050 Vol. 7 No. 3 (2020)
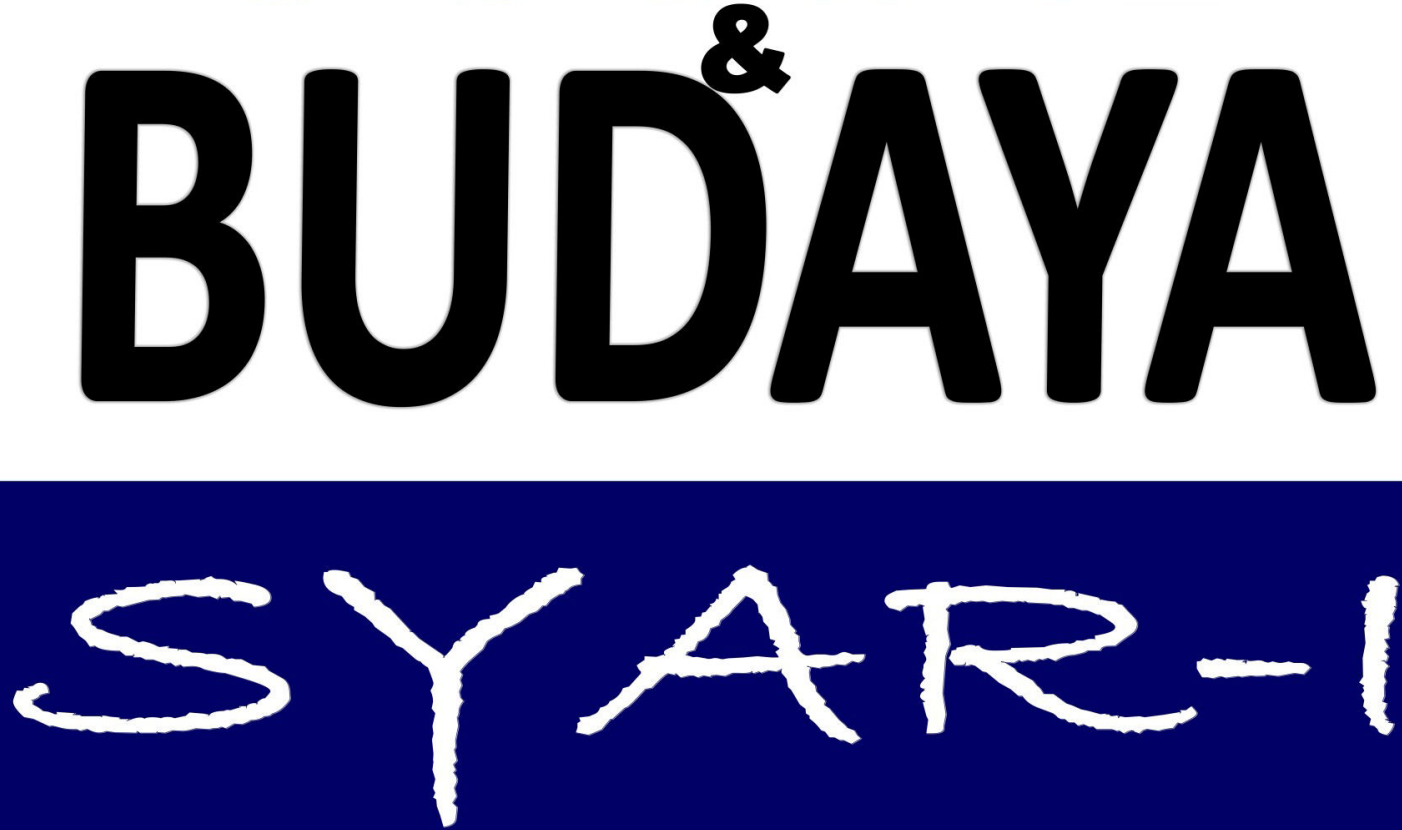

Konsep Tafakkur Dalam Alquran Dalam Menyikapi Coronavirus Covid-19 Indriya

Analisis Perilaku Masyarakat Indonesia dalam Menghadapi Pandemi Virus Corona (Covid-19) dan-

Kiat Menjaga Kesejahteraan Jiwa

Dana Riksa Buana

Kebijakan Pemberlakuan Lock Down Sebagai Antisipasi Penyebaran Corona Virus Covid-19

Nur Rohim Yunus, Annissa Rezki

Kebijakan Nabi Muhammad Saw Menangani Wabah Penyakit Menular dan Implementasinya dalam-

Konteks Menanggulangi Coronavirus Covid-19

Mukharom, Havis Aravik

Langkah Taktis Pemerintah Daerah Dalam Pencegahan Penyebaran Virus Corona Covid-19 di Indonesia Zahrotunnimah

Penggunaan Masker Penutup Wajah Saat Salat Sebagai Langkah Pencegahan Wabah Coronavirus Covid-19 Syandri, Fadhlan Akbar

Impact of Corona Virus Outbreak Towards Teaching and Learning Activities in Indonesia

Zaharah, Galia Ildusovna Kirilova, Anissa Windarti 


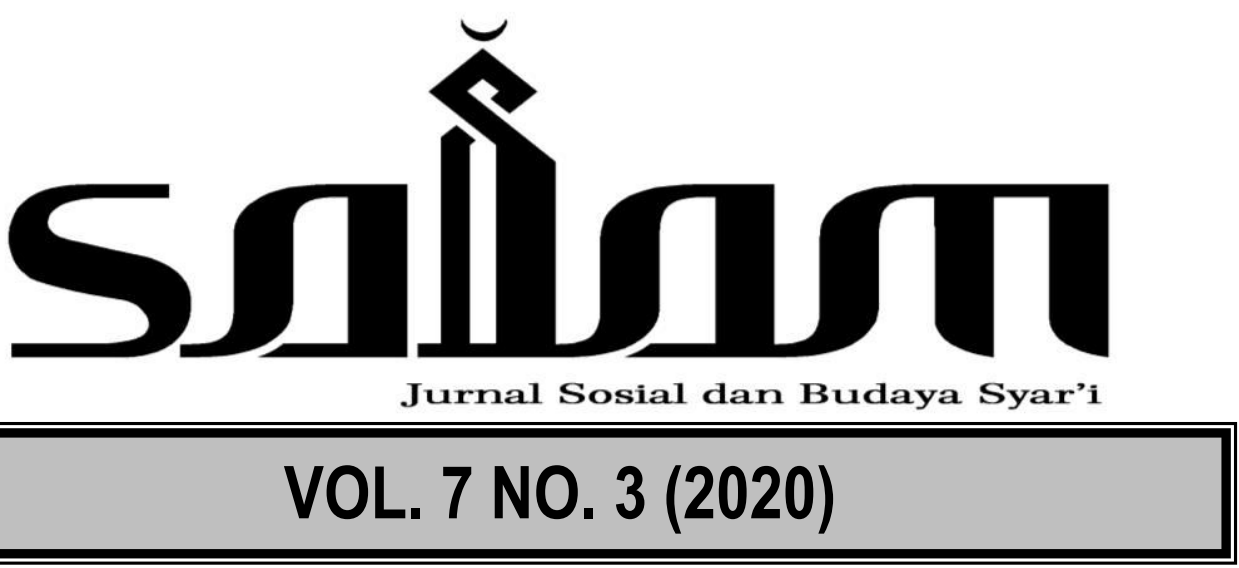

Diterbitkan oleh Fakultas Syariah dan Hukum Universitas Islam Negeri (UIN) Syarif Hidayatullah Jakarta.

Salam; Jurnal Sosial dan Budaya Syar-i mengkhususkan diri dalam pengkajian ilmu-ilmu Sosial dan Budaya dalam dimensi Syariah.

Terbit tiga kali dalam satu tahun di setiap bulan April, Agustus, dan Desember.

\section{Redaktur Ahli}

Muhammad Amin Suma (UIN Syarif Hidayatullah Jakarta) A Salman Maggalatung (UIN Syarif Hidayatull ah Jakarta) Asep Saepudin Jahar (UIN Syarif Hidayatullah Jakarta) Ahmad Mukri Aji (UIN Syarif Hidayatullah Jakarta) JM Muslimin (UIN Syarif Hidayatullah Jakarta) Muhammad Munir (IIU Islamabad Pakistan)

Euis Amalia (UIN Syarif Hidayatullah Jakarta)

Tim Lindsey (Melbourne University Australia)

Raihanah Azahari (University Malaya Malaysia)

Ahmad Tholabi (UIN Syarif Hidayatullah Jakarta)

Ahmad Hidayat Buang (University Malaya Malaysia)

\section{Pemimpin Redaksi \\ Erwin Hikmatiar}

\section{Sekretaris Redaksi}

Muhammad Ishar Helmi

Redaktur Pelaksana

Mara Sutan Rambe

Indra Rahmatullah

Nur Rohim Yunus

\section{Tata Usaha}

Imas Novita Juaningsih

Azizah Ratu Buana

\section{Alamat Redaksi}

Fakultas Syariah dan Hukum UIN Syarif Hidayatullah Jakarta Jl. Ir. H. Juanda 95 Ciputat Jakarta 15412 Telp. (62-21) 74711537, Faks. (62-21) 7491821

Website: www.fsh-uinjkt.net, E-mail: jurnal.salam@uinjkt.ac.id

Permalink: http://journal.uinjkt.ac.id/index.php/salam 


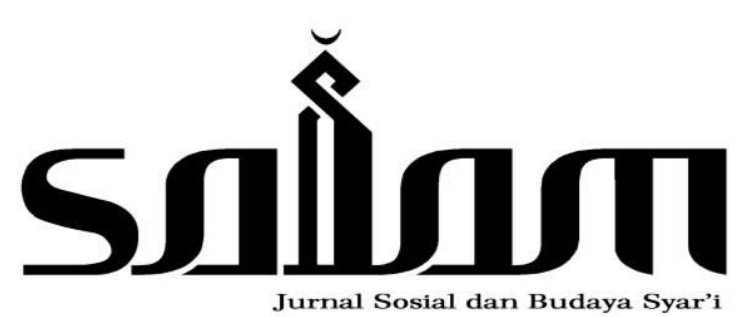

Menyambut baik kontribusi dari para ilmuwan, sarjana, profesional, dan peneliti dalam disiplin ilmu hukum untuk dipublikasi dan disebarluaskan setelah melalui mekanisme seleksi naskah, telaah mitra bebestari, dan proses penyuntingan yang ketat. 


\section{DAFTAR ISI}

\section{1-216}

Konsep Tafakkur Dalam Alquran Dalam Menyikapi Coronavirus Covid-19 Indriya

\section{7-226}

Analisis Perilaku Masyarakat Indonesia dalam Menghadapi Pandemi Virus Corona (Covid-19) dan Kiat Menjaga Kesejahteraan Jiwa

Dana Riksa Buana

\section{7-238}

Kebijakan Pemberlakuan Lock Down Sebagai Antisipasi Penyebaran Corona Virus Covid-19

Nur Rohim Yunus, Annissa Rezki

\section{9-246}

Kebijakan Nabi Muhammad Saw Menangani Wabah Penyakit Menular dan Implementasinya dalam Konteks Menanggulangi Coronavirus Covid-19 Mukharom, Havis Aravik

\section{7-260}

Langkah Taktis Pemerintah Daerah Dalam Pencegahan Penyebaran Virus Corona Covid-19 di Indonesia

Zahrotunnimah

\section{1-268}

Penggunaan Masker Penutup Wajah Saat Salat Sebagai Langkah Pencegahan Wabah Coronavirus Covid-19

Syandri, Fadhlan Akbar

\section{9-282}

Impact of Corona Virus Outbreak Towards Teaching and Learning Activities in Indonesia

Zaharah, Galia Ildusovna Kirilova, Anissa Windarti 



\title{
Konsep Tafakkur Dalam Alquran Dalam Menyikapi Coronavirus Covid-19*
}

\author{
Indriya $^{1}$ \\ Universitas Ibn Khaldun, Bogor, Jawa Barat \\ doi $10.15408 /$ sjsbs.v7i3.15050
}

\begin{abstract}
:
Tafakkur in Arabic is interpreted as an act of thinking to bridge the perceptions and conceptions of this world life to the afterlife, and from creatures to their Creator, namely Allah. Tafakkur goes beyond this life to a wider region, the hereafter, and transcends the superficiality of materialism to a deeper horizon, that is "spirit" which can motivate all external and internal activities of Muslims. According to Ibn Khaldun in the book Mukadimmah has a fairly broad understanding. Education is not only a teaching and learning process that is limited by four walls, but education is a process in which humans consciously capture, absorb, and experience natural events throughout the ages. This study aims to treat the epidemic of the Covid 19 virus corona with an Islamic Education perspective approach. This research is a qualitative research with a literature review approach. The results found that the tafakkur corona Covid 19 virus in the perspective of the Islamic religion produced findings through, namely; first, quarantine, namely isolating the area affected by the plague is an appropriate action; Second, be patient; Third, be kind and work hard; Fourth, pray a lot.
\end{abstract}

Keywords: Tafakkur, Islamic Religious Education, Corona virus Covid 19

\begin{abstract}
Abstrak
Tafakkur dalam bahasa Arab diartikan sebagai tindakan berpikir untuk menjembatani persepsi dan konsepsi dari kehidupan dunia ini ke kehidupan akhirat, dan dari makhluk ke Penciptanya, yaitu Allah Swt. Tafakkur melampaui hidup ini ke wilayah lebih luas, akhirat, dan melampaui kedangkalan materialisme menuju horizon lebih dalam, yaitu "ruh" yang dapat memotivasi seluruh aktivitas eksternal dan internal kaum muslim. Menurut Ibn Khaldun di dalam buku Mukadimmah mempunyai pengertian yang cukup luas. Pendidikan bukan hanya merupakan proses belajar mengajar yang dibatasi oleh empat dinding, tetapi pendidikan adalah suatu proses dimana manusia secara sadar menangkap, menyerap, dan menghayati peristiwa-peristiwa alam sepanjang zaman. Penelitian ini bertujuan untuk mentafakkuri wabah corona virus Covid 19 dengan pendekatan perspektif Pendidikan Islam. Penelitian ini merupakan penelitian kualitatif dengan pendekatan literature review. Hasil penelitian menemukan bahwa tafakkur corona virus Covid 19 dalam perspektif Agama Islam menghasilkan temuan melalui, yaitu; pertama, karantina yaitu mengisolasi daerah yang terkena wabah adalah sebuah tindakan yang tepat; Kedua, bersabar; Ketiga, berbaik sangka dan berikhtiarlah; Keempat, banyak berdoalah.
\end{abstract}

Kata Kunci: Tafakkur, Pendidikan Agama Islam, Coronavirus Covid 19

*Diterima: 18 Februari 2020, Revisi: 20 Februari 2020, Diterbitkan 18 Maret 2020.

${ }^{1}$ Dosen pada Prodi Pendidikan Agama Islam, Universitas Ibn Khaldun, Bogor, Jawa Barat. Email: indriya.rusmana1@gmail.com. 


\section{Pendahuluan}

Akhir tahun 2019 dunia dikejutkan dengan adanya penyebaran corona virus yang dikenal dengan covid-19. Dinamakan demikian karena kemunculannya di akhir tahun 2019. Virus ini pertama kali ditemukan endemic di kota Wuhan, provinsi Hubei, RRC. Awalnya diduga berasal dari hewan kelelawar sebagai inangnya yang berpindah pada manusia pemakan kelelawar. Selain pendapat ini, ada juga yang mengatakan kalau covid 19 merupakan mutasi dari virus SARS yang juga pertama kali ditemukan di Cina pada tahun 2002, yang cepat menyebar ke berbagai negara, walaupun bukan pandemi, dan kemudian virus ini bahkan sempat hilang di tahun 2004.

Namun pada kenyataannya ternyata virus ini tidak benar-benar hilang, bahkan dalam masa inkubasinya virus dapat menular pada manusia, dan bisa berpindah kepada orang lain melalui tangan orang sehat yang berpegangan tangan, atau berbagai barang yang terkena virus orang sakit, melalui percikan batuknya. Tangan dan jemari manusia yang menjadi alat transportasi virus masuk ke tubuh manusia. Sejauh ini menurut para ahli, virus ini tidak berpindah melalui udara.

Di Cina sendiri dalam tempo singkat perpindahan virus dari orang sudah lintas provinsi, yang berlanjut lintas negara dan kini lintas benua. Sampai akhirnya WHO pada tanggal 12 Maret 2020 telah menyatakan sebaran virus covid-19 sebagai pandemic. Tercatat 156 negara dan telah menginfeksi sebanyak 167.740 orang, meninggal 6.456 orang, dan sembuh 76.598 orang, sedangkan 5.811 orang dalam kondisi kritis. $^{2}$

\section{Metode Penelitian}

Penelitian ini menggunakan metode penelitian kualitatif deskriptif, karena metode ini merupakan upaya memahami berbagai konsep yang ditemukan dalam proses penelitian. Penelitian yang digunakan pada kondisi obyek yang alamiah, dimana peneliti sebagai instrumen kunci, pengambilan sample sumber data dilakukan secara purposif dan snowball, tekhnik pengumpulan data dengan triangulasi (gabungan) analisis data bersifat induktif/kualitatif, dan hasil penelitian kualitatif lebih menekankan makna dari generalisasi. Sedangkan untuk pengumpulan data peneliti menggunakan beberapa tekhnik pengumpulan data penelitian, yaitu observasi, wawancara, dan studi dokumentasi. Kemudian data tersebut direduksi, didisplay dan disajikan sesuai dengan prosedur penelitian.

\section{Kajian Litelatur}

Pandangan Alquran mengenai manusia sebagai khalifah memiliki tugas mulia dan misi besar untuk dijalankan di muka bumi, sebagaimana dikemukakan dengan jelas di dalam beberapa ayat Alquran, salah satunya di dalam QS. Az-Zariyat (51) ayat 56: "Aku tidak menciptakan jin dan manusia melainkan agar mereka beribadah kepada-Ku."

\footnotetext{
${ }^{2}$ Disadur oleh : Dr.Abidinsyah Siregar (Ahli Utama BKKBN dpk Kemenkes RI/ Ketua Departemen Kesehatan dan Sanitasi Lingkungan PP DMI/ Ketua PP IPHI/ Ketua PP ICMI/ Dewan Pakar PB IDI).
} 
Berdasarkan hal ini-lah bertafakkur tentunya menjadi salah satu ciri penting, bukan saja yang membedakan manusia dengan mahluk lainnya, tetapi juga menjadi salah satu prasyarat melaksanakan peran penting sebagai khalifah, untuk mengemban pembangunan peradaban sekaligus pembawa visi misi di muka bumi. Dalam istilah Arab, tafakkur artinya berpikir. Menurut Al-Fairuzabadi, salah seorang linguistic Muslim awal terkemuka, al-fikr (pikiran) adalah refleksi atas sesuatu: afkar adalah bentuk jamaknya. Menurut pandangannya, fikr dan tafakkur adalah sinonim dan keduanya memiliki makna sama.

Menurut Profesor Malik Badri, seorang psikolog Muslim kontemporer, menjelaskan perbedaan antara tafkir dan tafakkur. Tafakkur lebih dalam dan lebih luas ketimbang tafkir. Tafakkur menjembatani persepsi dan konsepsi dari kehidupan dunia ini ke akhirat dan dari makhluk ke Penciptanya, Allah Swt. Perantaraan ini dikenal dengan $i^{\prime}$ tibar. Jadi, tafkir bisa jadi terbatas pada pemecahan masalah hidup kita saat ini yang tak melibatkan emosi, namun, tafakkur melampaui hidup ini ke wilayah lebih luas, akhirat, dan melampaui kedangkalan materialisme menuju horizon lebih dalam, "ruh", dan dengan demikian tafakkur memotivasi seluruh aktivitas eksternal dan internal kaum muslim. ${ }^{3} \mathrm{Di}$ dalam Alquran terdapat 18 kali yang mengulang-ulang mengenai taffakur, salah satunya Allah Swt menyampaikan Firman-NYA di dalam QS. An-Nahl (16) ayat 11: "Dengan (air hujan) itu Dia menumbuhkan untuk kamu tanamtanaman, zaitun, kurma, anggur dan segala macam buah-buahan. Sungguh, pada yang demikian itu benar-benar terdapat tanda (kebesaran Allah) bagi orang yang berpikir.

Adapun pengertian Pendidikan Islam menurut Muhaimin dapat dipahami dalam beberapa perspektif, yaitu:

Pertama; Pendidikan menurut Islam, atau pendidikan yang berdasarkan Islam dan sistem pendidikan yang Islami, yakni pendidikan yang dipahami dan dikembangkan serta disusun dari ajaran dan nilai-nilai fundamental yang terkandung dalam sumber dasarnya, yaitu Al-quran dan Al-sunnah/hadits. Dalam pengertian yang pertama ini, pendidikan Islam dapat berwujud pemikiran dan teori pendidikan yang mendasarkan diri atau dibangun dan dikembangkan dari sumber-sumber dasar tersebut.

Kedua; Pendidikan ke-Islaman atau pendidikan agama Islam, yakni upaya mendidikan agama Islam atau ajaran Islam dan nilai-nilainya, agar menjadi way of life (pandangan dan sikap hidup) seseorang. Dalam pengertian yang kedua ini dapat berwujud (a) segenap kegiatan yang dilakukan seseorang dalam membantu seorang atau sekelompok peserta didik dalam menanamkan dan menumbuhkembangkan ajaran Islam dan nilai-nilainya untuk dijadikan sebagai pandangan hidupnya, yang diwujudkan dalam sikap hidup dan dikembangkan dalam keterampilan hidupnya sehari-hari; (b) segenap fenomena atau peristiwa perjumpaan antara dua orang atau lebih yang dampaknya ialah tertanamnya and tumbuh kembangnya ajaran Islam dan nilai-nilainya pada salah satu atau beberapa pihak.

\footnotetext{
${ }^{3}$ Jamal Badi, Mustapha Tajdin, Islamic Creative Thingking, Mizan, Bandung: 2007
} 
Ketiga: Pendidikan dalam Islam, atau proses dan praktik penyelenggaraan pendidikan yang berlangsung dan berkembang dalam sejarah umat Islam. Dalam arti proses bertumbuhkembangnya Islam dan umatnya, baik Islam sebagai agama, ajaran maupun sistem budaya dan peradaban, sejak zaman Nabi Muhammad Saw sampai sekarang. Jadi dalam pengertian yang ketiga ini istilah "pendidikan Islam" dapat dipahami sebagai proses pembudayaan dan pewarisan ajaran agama, budaya dan peradaban umat Islam dari generasi ke generasi sepanjang sejarahnya. ${ }^{4}$

Pendidikan Islam menurut Ahmad Tafsir berpendapat bahwa pendidikan agama Islam adalah bimbingan yang diberikan seseorang kepada seseorang agar ia berkembang secara maksimal seusia dengan ajaran Islam. ${ }^{5}$ Sedangkan menurut Ibn Khaldun di dalam buku Mukadimmah mempunyai pengertian yang cukup luas. Pendidikan bukan hanya merupakan proses belajar mengajar yang dibatasi oleh empat dinding, tetapi pendidikan adalah suatu proses, dimana manusia secara sadar menangkap, menyerap, dan menghayati peristiwa-peristiwa alam sepanjang zaman. ${ }^{6}$

Dari beberapa pengertian diatas, maka dapat disimpulkan bahwa pendidikan Islam adalah usaha-usaha dalam mendidikan Islam secara terencana melalui pengalaman, pengetahuan, kecakapan, dan keterampilan, sehingga peserta didik dapat mengenal, memahami, menghayati dan mengimani ajaran Islam.

\section{Hasil dan Pembahasan}

Sebagai orang yang beriman dengan memahami pengertian tafakkur dan pendidikan Islam di atas dalam menghadapi Coronavirus Covid-19, yang merupakan virus yang pertama kali ditemukan di Wuhan Cina pada Desember 2019. Kita semua dapat bertafakkur juga dengan kisah yang pernah terjadi saat zaman kekhalifahan Umar bin Khattab, dimana pada zaman pemerintahan beliau ini pernah terjadi wabah yang bermula di daerah Awamas, sebuah kota sebelah barat Yerussalem, Palestina, sehingga dinamakan demikian. Di dalam buku biografi Umar bin Khattab karya Muhammad Husein Haekal menjelaskan, wabah tersebut menjalar hingga ke Syam (Suriah), bahkan ke Irak. Diperkirakan kejadian wabah ini akhir 17 Hijriah, dan memicu kepanikan massal saat itu. Di dalam sebuah hadis yang disampaikan Abdurrahman bin Auf mengenai sabda Nabi SAW: "Apabila kalian mendengar wabah tha'un melanda suatu negeri, maka janganlah kalian memasukinya. Adapun apabila penyakit itu melanda suatu negeri sedang kalian kalian di dalamnya, maka janganlah kalian lari keluar dari negeri itu." (Muttafaqun 'alaihi, HR. Bukhari \& Muslim).

Pada akhirnya wabah tersebut berhenti ketika sahabat Amr bin Ash ra memimpin Syam. Kecerdasan beliau-lah dan dengan ijin Allah Swt yang menyelamatkan Syam. Amr bin Ash berkata: "Wahai sekalian manusia, penyakit ini menyebar layaknya kobaran api. Maka hendaklah berlindung dari penyakit ini ke bukit-bukit!". Saat itu seluruh warga mengikuti anjurannya. Amr bin Ash dan para

\footnotetext{
${ }^{4}$ Muhaimin, Pembangan Kurikulum Pendidikan Agama Islam di Sekolah Madrasah dan Perguruan Tinggi, Jakarta: PT. Raja Grafindo Persada, 2005

${ }^{5}$ Ahmad Tafsir, Ilmu Pendidikan Islam, Bandung: Rosda, 2012

${ }^{6}$ Ibnu Khaldun, Mukaddimah, Jakarta: Pustaka Al-Kautsar, 2014
} 
pengungsi terus bertahan di dataran-dataran tinggi hingga sebaran wabah Amawas mereda dan hilang sama sekali.

Dari kisah di atas kita semua dapat belajar dari orang-orang terbaik bersikap, dan juga yang telah dicontohkan oleh Rasulullah Saw. Apa yang dapat kita ambil ibrah atau pembelajarannya adalah:

\section{Pertama, karantina.}

Sebagaimana sabda Rasulullah SAW diatas, itulah konsep karantina yang hari ini dikenal. Mengisolasi daerah yang terkena wabah, adalah sebuah tindakan yang tepat. Kita bisa melihat dari sebuah tabel dibawah ini, bersumber dari harian Washington Post.

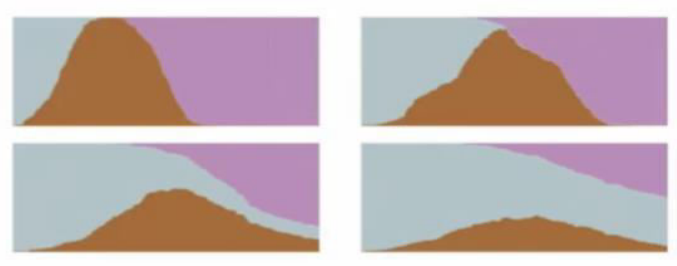

Keterangan bebasnya dapat diartikan sebagai berikut, searah jarum jam:

1) Orang bergerak bebas, dimana orang menularkan corona secara bersamaan.

2) Kurva kedua dilakukan lockdown, sehingga ada waktu untuk bisa melakukan penyembuhan secara bertahap.

3) Kurva ketiga dilakukan "social distancing", dengan berdiam diri di rumah dan mengurangi berbagai kegiatan sementara waktu.

4) Kurva keempat dilakukan dengan sangat extreme, dengan melakukan jam malam dan sangat ketat, untuk tidak keluar rumah bahkan diberikan jam waktu. $^{7}$

\section{Kedua, bersabar.}

Di dalam sebuah hadis riwayat Imam Bukhari diceritakan, suatu kali Aisyah bertanya kepada Nabi SAW tentang wabah penyakit. Rasulullah SAW bersabda,

"Wabah penyakit itu adalah orang-orang yang DIA kehendaki. Allah menjadikannya sebagai rahmat bagi orang-orang yang beriman. Jika terjadi suatu wabah penyakit, ada orang yang menetap di negerinya, ia bersabar, hanya berharap balasan dari Allah Swt. Ia yakin tidak ada peristiwa yang terjadi kecuali sudah ditetapkan Allah. Maka, ia mendapat balasan seperti mati syahid."

\section{Ketiga, berbaik sangka dan berikhtiarlah.}

Karena Rasulullah SAW bersabda: "Tidaklah Allah SWT menurunkan suatu penyakit kecuali Dia juga yang menurunkan penawarnya." (HR. Bukhari).

Dalam kisah Umar bin Khattab berikhtiar menghindarinya, serta Amr bin Ash berikhtiar menghapusnya. Istilah saat ini dan sedang kita lakukan adalah melakukan

\footnotetext{
${ }^{7}$ Washington post, 2020
} 
"social distancing", dilansir dari The Atlantic, tindakan yang bertujuan untuk mencegah orang sakit melakukan kontak dalam jarak dekat dengan orang lain untuk mengurangi peluang penularan virus. Artinya juga sementara waktu menjauhi perkumpulan, menghindari pertemuan massal, dan menjaga jarak antar manusia.

\section{Keempat, banyak berdoalah.}

Perbanyak doa-doa keselamatan, salah satu contohnya yang sudah diajarkan Rasulullah Saw untuk dilafadzkan di setiap pagi dan sore berikut ini:

"Bismillahilladzi laa yadhurru maasmihi, say'un fil ardhi walafissamaai wahuwa samiul'alim."

"Dengan nama Allah yang apabila disebut, segala sesuatu dibumi dan langit tidak berbahaya. Dialah maha mendengar dan maha mengetahui).

Barang siapa yang membaca dzikir tersebut $3 x$ dipagi dan petang. Maka tidak akan ada bahaya yg memudharatkannya. (HR. Abu Dawud dan Tirmidzi)

Berdasarkan pemahaman Spiritualism dan Rasionalism dapat dikatakan juga, seseorang yang memiliki tingkat spiritual tinggi, maka akan memiliki hormon endorphin yang lebih banyak dibandingkan dengan yang tingkat spiritual rendah. Mengapa bisa demikian? Walaupun belum ditemukan penelitian secara ilmiahnya, namun logikanya secara sederhana bisa kita perhatikan pada orang yang jauh dari Allah Swt, biasanya mudah mengalami stress, pada kondisi stress hormon yang bekerja adalah adrenalin, norepinephrine dan kortisol. Hormon stress akan menyebabkan asam lambung naik, sistem imun turun, sehingga mudah terkena penyakit. Sebaliknya pada oang-orang yang beriman dan tawakal, hormon oxytocin bekerja lebih baik, sehingga akan menghasilkan endorphin yang tinggi yang menimbulkan kedamaian, ketenangan sehingga sistem imun tubuh menjadi lebih kuat.

Terkait dengan wabah coronavirus covid 19 ini, sebagai seorang mu'min, maka sebaiknya selain melakukan juga ikhtiar karantina atau "social distancing" ini, maka tingkatkan juga spiritual kita. Jika dapat bertafakkur lebih jauh, sebagai muslim semua wabah ini adalah sebuah rahmatNYA, sebuah peringatan bagi yang berpikir, untuk terus menjadikannya sebagai wasilah atau jalan untuk terus banyak mendekatkan diri kepada Allah Swt, sehingga ketika tingkat kepasrahan tinggi maka akan dirasakan ketenangan dan dengan segala usaha dan doa keselamatan juga kepada Allah Swt, dengan selalu melibatkanNYA, dan berharap semua wabah ini akan berakhir, dan dapat pula segera ditemukan penyebabnya, InshaAllah AamiinYRA. Dialah Allah Sang Maha Pencipta lagi Maha Mengetahui.[]

\section{Referensi:}

Badi, Jamal; Tajdin, Mustapha (2007) Islamic Creative Thingking, Bandung: Mizan

Muhaimin, (2005) Pembangan Kurikulum Pendidikan Agama Islam di Sekolah Madrasah dan Perguruan Tinggi, Jakarta: PT. Raja Grafindo Persada

Siregar, Dr. Abidinsyah (2020) Jakarta: Ahli Utama BKKBN dpk Kemenkes RI/ Ketua Departemen Kesehatan dan Sanitasi Lingkungan PP DMI/ Ketua PP IPHI/ Ketua PP ICMI/ Dewan Pakar PB IDI.

Khaldun, Ibnu (2014) Mukaddimah, Jakarta: Pustaka Al-Kautsar

Tafsir, Ahmad (2012) Ilmu Pendidikan Islam, Bandung: Rosda 


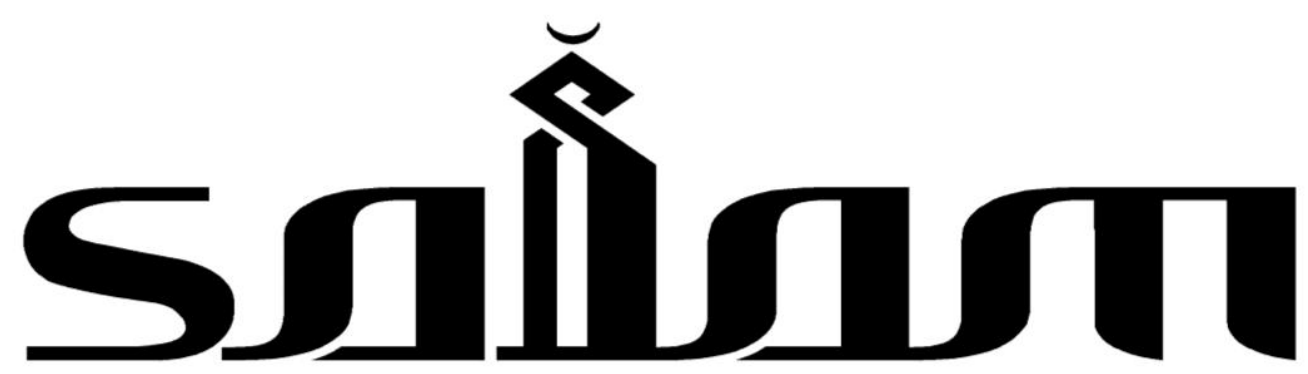

Jumnal Sosial dan Budaya Syar'i

\section{PEDOMAN TEKNIS PENULISAN BERKALA ILMIAH}

1. Artikel adalah benar-benar karya asli penulis, tidak mengandung unsur plagiasi, dan belum pernah dipublikasikan dan/atau sedang dalam proses publikasi pada media lain yang dinyatakan dengan surat pernyataan yang ditandatangani di atas meterai Rp 6000;

2. Naskah dapat berupa konseptual, resume hasil penelitian, atau pemikiran tokoh;

3. Naskah dapat berbahasa Indonesia, Inggris, Arab, maupun bahasa Rusia;

4. Naskah harus memuat informasi keilmuan dalam ranah ilmu hukum Positif;

5. Aturan penulisan adalah sebagai berikut:

a. Judul. Ditulis dengan huruf kapital, maksimum 12 kata diposisikan di tengah (centered);

b. Nama penulis. Ditulis utuh, tanpa gelar, disertai afiliasi kelembagaan dengan alamat lengkap, dan alamat e-mail;

c. Abstrak. Ditulis dalam bahasa Inggris dan Bahasa Indonesia antara 80-120 kata;

d. Sistematika penulisan naskah adalah sebagai berikut:

1) Judul;

2) Nama penulis (tanpa gelar akademik), nama dan alamat afiliasi penulis, dan e-mail;

3) Abstrak ditulis dalam dua bahasa, yaitu bahasa Indonesia dan Inggris, antara 80-120 kata;

4) Kata-kata kunci, antara 2-5 konsep yang mencerminkan substansi artikel;

5) Pendahuluan;

6) Sub judul (sesuai dengan keperluan pembahasan);

7) Penutup; dan

8) Pustaka Acuan (hanya memuat sumber-sumber yang dirujuk dan sedapat mungkin terbitan 10 tahun terakhir).

e. Ukuran kertas yang digunakan adalah kertas HVS 70 gram, ukuran A4, margin: atas $3,5 \mathrm{~cm}$, bawah $3.5 \mathrm{~cm}$, kiri $3,5 \mathrm{~cm}$, dan kanan $3,5 \mathrm{~cm}$;

f. Panjang Naskah antara 13 s.d. 15 halaman, spasi 1, huruf Palatino, ukuran 11;

g. Pengutipan kalimat. Kutipan kalimat ditulis secara langsung apabila lebih dari empat baris dipisahkan dari teks dengan jarak satu spasi dengan ukuran huruf 10 point. Sedangkan kutipan kurang dari empat baris diintegrasikan dalam teks, dengan tanda apostrof ganda di awal dan di akhir kutipan. Setiap kutipan diberi nomor. Sistem pengutipan adalah footnote (bukan bodynote atau endnote). Penulisan footnote menggunakan sistem turabian. Setiap artikel, buku, dan sumber lainnya yang dikutip harus tercantum dalam pustaka acuan;

h. Pengutipan Ayat Alquran dan Hadis. Ayat yang dikutip menyertakan keterangan ayat dalam kurung, dengan menyebut nama surah, nomor surah, dan nomor ayat, seperti (Q.s. al-Mu'min [40]: 43). Pengutipan Hadis menyebutkan nama perawi (H.r. al-Bukhārĩ dan Muslim) ditambah referensi versi cetak kitab Hadis yang dikutip. Hadis harus dikutip dari kitab-kitab Hadis standar (Kutub al-Tis'ah);

i. Cara pembuatan footnote. Footnote ditulis dengan font Palation size 9, untuk pelbagai sumber, antara lain: 
1) Buku: nama utuh penulis (tanpa gelar), judul buku (tempat terbit: penerbit, tahun terbit), cetakan, volume, juz, halaman. Contoh: Soerjono Soekanto, Pokok-pokok Sosiologi Hukum, (Jakarta: Rajawali Pers, 1986), h. 10.

2) Buku terjemahan, contoh: Roscoe Pound, Pengantar Filsafat Hukum: Buku III, diterjemahkan oleh Moh. Radjab, (Jakarta: Bharata, 1963), h. 15;

1) Jurnal, contoh: Nur Rohim, "Kontroversi Pembentukan Perppu No. 1 Tahun 2013 tentang mahkamah konstitusi dalam ranah kegentingan yang memaksa", dalam Jurnal Cita Hukum, Vol. 2, No. 1 (2014), h. 157.

2) Artikel sebagai bagian dari buku (antologi), contoh: Hikmahanto Juwana, "Penegakan Hukum dalam Kajian Law and Development: Problem dan Fundamen bagi Solusi Indonesia", dalam Muhammad Tahir Azhary, Beberapa Aspek Hukum Tata Negara, Hukum Pidana, dan Hukum Islam, (Jakarta: Kencana Prenada Media Gorup, 2012), h. 127.

3) Artikel dari internet, contoh: Ahmad Tholabi Kharlie, "Problem Yuridis RUU Syariah" dalam http://ahmadtholabi.com/2008/03/03/problem-yuridis-ruu-syariah, diunduh pada 20 Maret 2012.

4) Artikel dari majalah, contoh: Susilaningtias, "Potret Hukum Adat pada Masa Kolonial", dalam Forum Keadilan, No. 17, 20 Agustus 2006.

5) Makalah dalam seminar, contoh: Jimly Asshiddiqie, "Kedudukan Mahkamah Konstitusi dalam Struktur Ketatanegaraan Indonesia", Makalah disampaikan dalam Kuliah Umum Fakultas Hukum Universitas Sebelas Maret, Surakarta, pada 2 Maret 2004.

j. Pustaka Acuan: daftar pustaka acuan ditulis sesuai urutan abjad, nama akhir penulis diletakkan di depan. Contoh:

1) Buku, contoh: Soekanto, Soerjono, Pokok-pokok Sosiologi Hukum, Jakarta: Rajawali Pers, 1986.

2) Buku terjemahan, contoh: Pound, Roscoe, Pengantar Filsafat Hukum: Buku III, diterjemahakan oleh Moh. Radjab, Jakarta: Bharata, 1963.

3) Jurnal, contoh: Rohim, Nur, "Kontroversi Pembentukan Perppu No. 1 Tahun 2013 tentang mahkamah konstitusi dalam ranah kegentingan yang memaksa", dalam Jurnal Cita Hukum, Vol. 2, No. 1 (2014).

4) Artikel sebagai bagian dari buku, contoh: Juwana, Hikmahanto, "Penegakan Hukum dalam Kajian Law and Development: Problem dan Fundamen bagi Solusi Indonesia", dalam Muhammad Tahir Azhary, Beberapa Aspek Hukum Tata Negara, Hukum Pidana, dan Hukum Islam, Jakarta: Kencana Prenada Media Gorup, 2012.

5) Artikel yang dikutip dari internet, contoh: Kharlie, Ahmad Tholabi, "Problem Yuridis RUU Syariah" dalam http://ahmadtholabi.com/2008/03/03/problem-yuridis-ruu-syariah, diunduh pada 20 Maret 2012.

6) Majalah, contoh: Susilaningtias, "Potret Hukum Adat pada Masa Kolonial", dalam Forum Keadilan, No. 17, 20 Agustus 2006.

7) Makalah dalam seminar, contoh: Asshiddiqie, Jimly, "Kedudukan Mahkamah Konstitusi dalam Struktur Ketatanegaraan Indonesia", Makalah disampaikan dalam Kuliah Umum Fakultas Hukum Universitas Sebelas Maret, Surakarta, pada 2 Maret 2004.

k. Penutup: artikel ditutup dengan kesimpulan;

I. Biografi singkat: biografi penulis mengandung unsur nama (lengkap dengan gelar akademik), tempat tugas, riwayat pendidikan formal (S1, S2, S3), dan bidang keahlian akademik;

6. Setiap naskah yang tidak mengindahkan pedoman penulisan ini akan dikembalikan kepada penulisnya untuk diperbaiki.

7. Naskah sudah diserahkan kepada penyunting, selambat-lambatnya tiga bulan sebelum waktu penerbitan (April, Agustus. dan Desember) dengan mengupload pada laman OJS jurnal pada alamat http://journal.uinjkt.ac.id/index.php/salam atau dikirim langsung via e-mail ke: jurnal.salam@gmail.com atau nurrohimyunus@uinjkt.ac.id..] 


\section{Indexed by :}
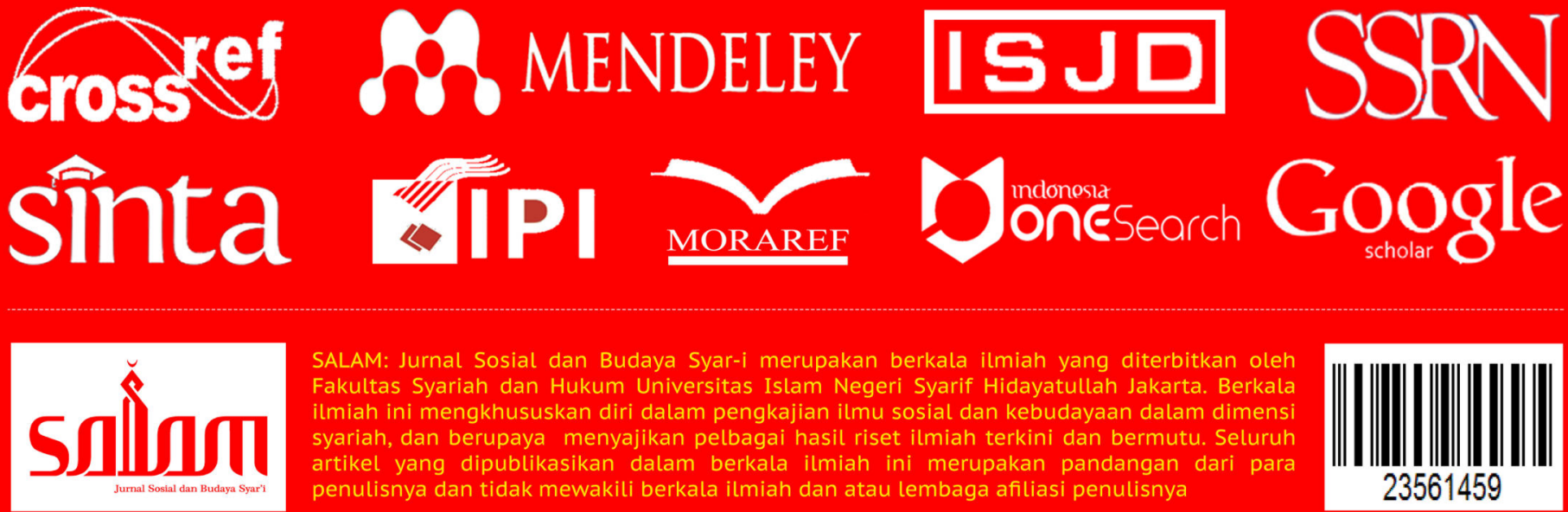

SALAM: Jurnal Sosial dan Budaya Syar-i merupakan berkala ilmiah yang diterbitkan oleh Fakultas Syariah dan Hukum Universitas Islam Negeri Syarif Hidayatullah Jakarta. Berkala ilmiah ini mengkhususkan diri dalam pengkajian ilmu sosial dan kebudayaan dalam dimensi syariah, dan berupaya menyajikan pelbagai hasil riset ilmiah terkini dan bermutu. Seluruh artikel yang dipublikasikan dalam berkala ilmiah ini merupakan pandangan dari para penulisnya dan tidak mewakili berkala ilmiah dan atau lembaga afiliasi penulisnya

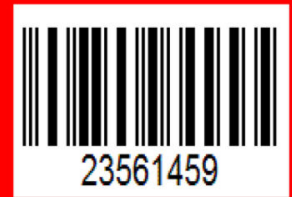

